\title{
THE CUSTOMARY LAW OF INTERNATIONAL ABDUCTIONS: LIMITS AND BOUNDARIES*
}

\author{
Abraham Mohit** \\ 1. INTRODUCTION \\ "Once a person is under the authority of a given court and has been properly charged \\ in accordance with the local law, he may be tried and, if convicted, sentenced by \\ that court regardless of the mode by which he was brought originally under the \\ authority of that court". ${ }^{1}$
}

During his exile in Kolonos, Oedipus had to defend himself against the horse-riding agents of Thebes who tried to force him back into Theban territory. Adolf Eichmann was forced back into the territory of Israel, as have so many other criminal offenders been in the past. These situations have resulted in the evolution of the doctrine of mala captus bene detentus (wrongfully caught, legally detained) explained in the introductory quote.

However, over the years the position of this principle has undergone a great number of changes. There are conflicting opinions and practices of states. By and large, though, most states prohibit exercise of jurisdiction over accused caught illegally, primarily by resorting to abduction. It will be established in the course of this paper that there is in fact a strong case to conclude that a norm of customary international law has evolved in this regard.

\footnotetext{
* This article won the Sata International Law Prize 2004.

** Graduated with BA LL.B (Hons.) The WB National University of Juridical Sciences, and presently employed with an Indian law firm, Amarchand and Mangaldas, at Mumbai. I would like to express my deepest gratitude to Professor Mark Osiel for his insightful comments on an initial draft of this paper. I would also like to thank Professor Rafiqul Islam for his comments and support while I conducted research on this paper at Macquarie University, Sydney. Finally, thanks to my colleagues and friends Deepto, Saptarishi, Shobha, and Shravya for all their help. Needless to say, any errors remain mine.

${ }^{1}$ Glahn, Gerhard von, Law among Nations (6th ed., MacMillan, 1992), at 315. See also, Shaw, Malcolm, International Law ( $2^{\text {nd }}$ ed., Grotius, 1986), at 361: "unlawful apprehension is no defence to an exercise of jurisdiction."
}

Asian Yearbook of International Law, Volume 11 (B.S. Chimni et al., eds.)

(C) 2006 Koninklijke Brill NV. Printed in The Netherlands, pp. 123-146. 
The world order as it exists today, however, requires a re-examination of the new norm. Taking into consideration the increasing number of individuals accused of committing acts of terrorism, genocide and other crimes against humanity, whether states have over-reacted in their criticism of the rule of mala captus bene detentus needs to be examined. While the general rule is accepted, certain exceptions need to be carved out wherein the rule can apply. This paper would aim to spell out precisely those permissible limits which international law can accommodate.

On 15 June 1992, the United States Supreme Court rendered a landmark decision that affected not only American jurisprudence, but international law as well. United States v. Alvarez Machain ${ }^{2}$ was the beginning of a new dimension in the concepts of state sovereignty and the right to freedom from arbitrary arrest and detention. In this case the Supreme Court of the United States held that federal courts have jurisdiction over a defendant abducted from abroad under the auspices of governmental authority, despite the existence of an extradition treaty with the state from which he was abducted. Although the decision was narrowly written, it has become the template used by courts to analyze a range of similar events, which continue to surface. $^{3}$

The consequences of Alvarez-Machain are important not only for understanding the issues and for predicting outcomes for subsequent cases, but also for studying the evolution of international law in this regard. As will be argued in this paper, this is an example of how a particular incident and reactions to the same can result in a relatively rapid development of customary international law; particularly because it goes a long way in fulfilling the requirements of generality and consistency, apart from showing the necessary requirements of state practice and opinio juris.

In the aftermath of the decision, the United States signed an agreement with Mexico, the Treaty to Prohibit Transborder Abductions of November 23, 1994, that expressly provides for the prompt return of an abductee and strips domestic courts of jurisdiction to try such an individual. ${ }^{4}$ In so doing the agreement effectively overrules the Supreme Court's decision in Alvarez Machain. This change in opinion was largely provoked by strong opposition of foreign states and international bodies to the US Supreme Court's reasoning.

The rule contrary to mala captus bene detentus, had thus, begun to take form and this was primarily due to three reasons; a) the threat other countries perceived at allowing a free hand for increased interference by powerful countries like the United States b) the threat that such a rule might pose to the sovereignty of countries, and c) the increasing importance states began to attach to human rights issues.

\footnotetext{
2504 US 655 (1992).

3 Wilske, Stephan and Schiller, Teresa, "Jurisdiction over persons abducted in violation of international law in the aftermath of United States v. Alvarez Machain", 5 U.Chi.L.Sch.Roundtable (1998), at 205. See also Michell, Paul, "English-speaking justice: evolving responses to transnational forcible abduction after Alvarez-Machain", 29 Cornell ILJ (1996), at 383.

4 Treaty to Prohibit Transborder Abductions, signed 23 November 1994, United States-Mexico, in Abbell, Michael and Ristau, Bruno A., 5 International Judicial Assistance (Criminal) Extradition A-676.3 (Supp. 1995), in Wilske, n. 3.
} 
To what extent the alacrity and intensity of the shift in international opinion and thereby in customary international law, due to the fact that it was the United States that employed this practice, is concerned is also a crucial question which needs to be examined. This question is necessary because despite the affirmation of the rule prohibiting international abductions, in many instances states and International Tribunals have approved the use of such measures. Accordingly, would the absence of the influence of the United States [which in any event is perceived to "make its own international law"] have resulted in the rule's being formed differently? The impact of this aspect on the formation of a customary norm will also be discussed.

The boundaries of such a new rule of customary international law is under an ongoing test, as will be seen in cases of international abductions in the context of the various War Crimes Tribunals.

In the past, authors have analyzed this issue with regard to whether there is any recognized customary international law justifying irregular renditions, and have invariably concluded in the negative. ${ }^{5}$ This paper seeks to understand the evolution of such customary law and its precise limits and boundaries in today's world order. Along these lines, the paper will, therefore, seek to establish that although there is a customary rule which goes against the doctrine of mala captus bene detentus, certain exceptions also exist; in those circumstances states may utilize irregular methods of establishing jurisdiction, such as abducting the fugitives in order to bring them to justice, and there should not be a barrier in such an exercise of justice.

In the first part of this paper the customary status of the rule prohibiting mala captus bene detentus will be outlined by conducting a study of the practice of various jurisdictions, international bodies and international tribunals. Subsequently, the paper will show the circumstances in which courts may hold that an act of abduction would entitle the fugitive to being repatriated, and in which a violation of the sovereignty of the state from which the individual would have been abducted would have occurred. The paper will then finally seek to demonstrate the situations in which such acts may actually be justified.

\footnotetext{
5 See, e.g., Morgenstern, Felice, "Jurisdiction in seizures effected in violation of international law", 29 BYIL (1952), at 265; Garcia-Mora, Manuel R., "Criminal jurisdiction of a state over fugitives brought from a foreign country by force or fraud: a comparative study", 32 Ind.LJ (1957), at 427; Preuss, Lawrence, "Kidnapping of Fugitives from Justice on Foreign Territory", 29 AJIL (1935) 502; Lowenfeld, Andreas F., "U.S. law enforcement abroad: the constitution and international law, continued", 84 AJIL (1990), at 444; Id., "Kidnapping by government order: a follow-up", 84 AJIL (1990), at 712; O'Higgins, Paul, "Unlawful seizure and irregular extradition", 37 BYIL (1960), at 279; Halberstam, Malvina, "Agora: International Kidnapping”, 86 AJIL (1992), at 736, 744; Rayfuse, Rosemary, "International abduction and the United States Supreme Court: the law of the jungle reigns", 42 ICLQ (1993), at 892.
} 


\section{STATE PRACTICE VIS-À-VIS ALVAREZ-MACHAIN: SINGING TO A DIFFERENT TUNE}

The Alvarez-Machain case met with widespread criticism throughout the international community. ${ }^{6}$ Twenty-one co-sponsoring states introduced a General Assembly Resolution that would request an advisory opinion from the ICJ "on the question of the conformity with international law of certain acts involving the extraterritorial exercise of coercive power of a State and the subsequent exercise of criminal jurisdiction". 7 While the resolution seeking an advisory opinion has been repeatedly deferred ${ }^{8}$ the UN Working Group on Arbitrary Detention concluded that "the detention of Humberto Alvarez-Machain is declared to be arbitrary, being in contravention of Article 9 of the International Covenant on Civil and Political Rights". ${ }^{9}$ In the aftermath of the decision, the issue was addressed by various international bodies and judicial organs of countries, and also by international tribunals. The practice of states and the opinio juris surrounding the same both before and after the AlvarezMachainp case will be examined in this section.

\subsection{Judgment and opinions of national jurisdictions}

Until 1978, Commonwealth courts followed the American approach to the male captus bene detentus rule. Since 1978, however, a series of judicial decisions in New Zealand, Australia, South Africa, and the UK indicate that the mala captus rule is no longer good law in these countries.

\subsubsection{England}

England has traditionally been perceived as following the rule of mala captus bene detentus, based on precedent in Ex parte Susannah Scott. ${ }^{10}$ The accused, under indictment in England for perjury, was apprehended in Belgium and returned by an English police officer to England, where she was arrested. Lord Tenterden, CJ held that the court would not divest itself of jurisdiction over an individual detained on a criminal charge. The court observed that though her arrest may have violated Belgian law, this would not bar her prosecution in England, although she may retain a right of action against the English police officer for wrongful arrest in Belgium.

\footnotetext{
${ }^{6}$ See generally, Zaid, M., "Military might versus sovereign right: the kidnapping of Dr. Humberto Alvarez-Machain and the resulting fallout", 19 Houston JIL (1997), at 829.

7 UN Doc. A/47/249 (1992).

${ }^{8}$ See, Morris, V. and Bourloyannis, M. Vrailas, "The work of the Sixth Committee at the Forty-ninth session of the U.N. General Assembly", 89 AJIL (1995) 607, at 620.

9 Report of the Working Group on Arbitrary Detention, UN Commission on Human Rights, 50th Session, Agenda Item 10, UN Doc. E/CN.4/1994/27 (1993), at 139-10.

${ }_{10}$ Ex parte Susannah Scott, [1829] 109 Eng. Rep (KB), at 166.
} 
The US Supreme Court in Ker v. Illinois ${ }^{11}$ considered Scott to be one of the "authorities of highest respectability".

In Ex parte Elliott, ${ }^{12}$ the court reaffirmed the mala captus bene detentus rule, by not inquiring into the circumstances of the arrest. In Ex parte Mackeson, ${ }^{13}$ however, the court felt it necessary to put a stop to what it perceived to be overzealousness on the part of the English police in dealing with suspects abroad. What the court found illegal in this case was that a deportation order was utilized in the guise of extradition and, thus, the court held that upon its discretion, it could grant the application for prohibition and discharge the applicant. ${ }^{14}$

The House of Lords finally resolved the issue in Ex parte Bennett. ${ }^{15}$ In this case it was held that a transnational forcible abduction that circumvents extradition proceedings is an abuse of process such that a court should exercise its discretion to enter a stay of proceedings against the fugitive. The Law Lords explicitly rejected the approach taken by the majority of the US Supreme Court in Alvarez Machain. The defendant in this case claimed that he was arrested by South African police, forced onto a flight for New Zealand by way of Taipei, intercepted at Taipei by South African police, packed back onto a flight to South Africa and then, in violation of an order of the South African Supreme Court, forcibly placed on a flight from Johannesburg to Heathrow. In making their decision the Law Lords did not consider whether there was protest or acquiescence by Taiwanese and South African authorities, nor did they rely on evidence of any physical brutality. Lord Bridge of Harwich concluded: "To hold that the court may turn a blind eye to executive lawlessness beyond the frontiers of its own jurisdiction is, to my mind, an insular and unacceptable view". ${ }^{16}$ The court went on to emphasize that English Courts would have the discretion to decline jurisdiction in such cases.

From this it flows that that the English Courts would necessarily look into the facts and circumstances of each given instance, and would decide accordingly. ${ }^{17}$

\subsubsection{New Zealand}

In Regina v. Hartley, ${ }^{18}$ a discretionary approach, similar to that of England, has been followed. The appellate court in this case allowed the trial court to exercise its discretion in deciding whether to discharge a fugitive seized in Australia under an informal agreement between the Melbourne and Wellington police. The Court

\footnotetext{
11119 US 444.

12 Regina v. Officer Commanding Depot Battalion (Ex parte Elliott), 1 All ER 373 (KB 1949).

13 Regina v. Bow Street Magistrates (Ex parte Mackeson), 75 Crim App 24 (1981).

14 Ibid.

15 Regina v. Horseferry Road Magistrates' Court (Ex parte Bennett), [1994] 1 App Cas 42 (Eng. HL 1993).

16 Ibid., at $155 \mathrm{~g}$.

17 Ibid., at 356.

18 [1978] 2 NZLR 199 (Ct. App. Wellington).
} 
found that the trial court had discretion over the discharge even though there may have been no violation of international law. The Court observed:

Some may say that in the present case a New Zealand citizen attempted to avoid a criminal responsibility by leaving the country: that his subsequent conviction has demonstrated the utility of the short cut adopted by the police to have him brought back. But this must never become an area where it will be sufficient to consider that the end has justified the means. The issues raised by this affair are basic to the whole concept of freedom in society. ${ }^{19}$

It would accordingly be reasonable to conclude that New Zealand courts would not uphold jurisdiction in a case of forcible abduction. While Hartley provided no opportunity for the court to consider international law, one can assume, however, based on the judgment, that New Zealand is in favour of a rule of international law prohibiting the exercise of jurisdiction over an abducted person. ${ }^{20}$

\subsubsection{South Africa}

For decades, South African courts had rigidly followed the maxim of mala captus bene detentus, until a most remarkable deviation was made in State v. Ebrahim. ${ }^{2122}$ Ebrahim was abducted by South African police from Swaziland. Although there was an extradition treaty between South Africa and Swaziland, no formal request for extradition had been lodged. Swaziland also failed to file a complaint against the violation of its sovereignty after the seizure of Ebrahim from its territory. The Supreme Court, on appeal, reversed the lower court's decision of exercising jurisdiction over Ebrahim, and concluded that a South African court has no jurisdiction to try a person abducted by the state from foreign territory. ${ }^{23}$ The court reached this conclusion on three basic points: 1) the necessity to protect and promote human rights, 2) the importance of maintaining good international relations, and 3) a healthy administration of justice. ${ }^{24}$

\subsubsection{Zimbabwe}

Largely influenced by the Court of South Africa, in 1992, the Supreme Court of Zimbabwe overruled old precedents which had followed the mala captus bene detentus rule. In doing so it also relied on considerations of international law. In State

19 Ibid., at 216-217.

${ }^{20}$ Michell, loc. cit., n. 3.

2131 ILM 888.

22 Abrahams v. Minister of Justice, 1963 (4) SALR 542 (Cape); Ndhlovu v. Minister of Justice, 68 ILR 7 (Natal 1976); Nduli v. Minister of Justice, 69 ILR 145 (S Ct App Div 1977). See also Michell, loc. cit., n. 3.

${ }_{23}$ State v. Ebrahim, n. 22, at 899.

${ }^{24}$ Ibid., at 896. 
v. Beahan, ${ }^{25}$ after thoroughly considering Anglo-American precedents including United States v. Alvarez Machain and balancing them against State v. Ebrahim, the court concluded that in order to promote confidence in and respect for the administration of justice and to preserve the judicial process from contamination, a court should decline to compel an accused person to undergo trial in circumstances where his appearance before it has been facilitated by an act of abduction undertaken by the prosecuting states. It was further observed that there is an inherent objection to such a course on grounds both of public policy pertaining to coexistence and of mutual respect of sovereign nations.

Thus, Beahan stands as strong evidence of the prohibition of exercise of jurisdiction over a person abducted from abroad in violation of international law.

\subsubsection{Australia}

Australia soon followed New Zealand's lead in calling the mala captus bene detentus rule into question. In Levinge v. Director of Custodial Services, ${ }^{26}$ the fugitive faced trial for numerous cases of dishonesty in New South Wales. He claimed that he had been arrested by Mexican police at his home in Mexico, brought to the American border, and delivered into the custody of US FBI agents who then brought him into the US and held him until he was extradited to Australia. He argued that this forcible abduction rendered his subsequent extradition to Australia unlawful and an abuse of process, such that proceedings against him in Australia should be stayed. Moreover, he alleged that the Australian authorities had been aware of and even involved in his abduction from Mexico.

The court held that even where a person is brought into the jurisdiction of a court unlawfully, the court has undoubted jurisdiction to deal with him or her. However, it also has the discretion to decline jurisdiction if it is of the opinion that to exercise its discretion would involve an abuse of the court's process. It went on to observe that such abusive conduct may exist in cases where the regular machinery for extradition is bypassed and when the executive participates in unauthorized and unlawful removal of criminal suspects from a foreign jurisdiction.

No evidence could be established in Levinge that the Australian police were involved in the expulsion of the plaintiff from Mexico. The court did, however, imply that a forcible abduction would be a strong case for staying criminal proceedings in order to prevent abuse of process. Therefore, considering the above factors, it seems reasonable to conclude that an Australian Court will not exercise jurisdiction over a person abducted from abroad in violation of international law.

\subsubsection{Switzerland}

In a 1967 case, the Court found that the defendant's apprehension violated national due process and principles of extradition law under which apprehension of

251992 (1) SACR 307 (A).

269 NSWR 546 (Ct App 1987). 
a person by means of force or ruse was prohibited. ${ }^{27}$ Since the prosecutor knew of the circumstances surrounding the defendant's abduction and arrest, the court found that the knowledge alone sufficed to turn the private operation into state action which violated extradition law. Accordingly, Switzerland also adheres to a rule of enquiry into the circumstances in which an individual was apprehended.

\subsubsection{Israel}

In the extremely controversial case of Eichmann, ${ }^{28}$ Israel exercised jurisdiction against the Nazi war criminal, Adolf Eichmann, who was kidnapped from Argentina by Mossad agents. The case is often cited as a precedent for the rule of mala captus bene detentus. However, what has to be remembered is that the issue of jurisdiction of a court had already been settled by diplomatic means when the criminal proceedings started in the Eichmann case. In fact, prior to this, Argentina protested the violation of its sovereignty, and requested the return of Eichmann, eventually taking the matter to the United Nations. The Security Council adopted a resolution condemning the kidnapping and requesting Israel to make appropriate reparation. ${ }^{29}$

After Israel tendered an official apology for violating sovereign authority, Argentina waived further action on the abduction. What is to be noted here is that the violation of sovereignty of the host state had been established by the Security Council, which clearly goes to justify the rule prohibiting mala captus bene detentus.

\subsubsection{Costa Rica}

The national judicial tribunal of Costa Rica has not accepted the principle of exercising jurisdiction over individuals who have been abducted. The Supreme Court of Costa Rica unanimously censured the Alvarez-Machain decision of the U.S. Supreme Court, stating in the Court's plenary session of 25 June 1992:

Because of the profound harm to the rules of international law and to sovereignty of States that the resolution implies, this Court resolves to establish evidence so it be knowing in this way, of the inadmissibility of such pronouncement, and has no doubt that shortly, it will be amended by the same Court who has issued it, in support of supremacy of law and mutual respect that must rule between the United States and all other States ... ${ }^{30}$

The resolution expressly refers to international law as a legal bar to the exercise of jurisdiction.

2766 Blatter fur Zurcherische Rspr (1967), at 248, in Wilske and Schiller, loc. cit., n. 3.

2836 ILR 18 (Dist Ct Jerusalem 1961); 36ILR 277 (Sup Ct 1962).

29 See generally UN SCOR, UN Doc.S/RES/4349 (1960).

${ }^{30}$ Secretaria de Relaciones Exteriores, 2 Limits to National Jurisdiction: Documents and Judicial Resolutions on the Alvarez Machain Case (1993) 7, at 81-82. 


\subsection{Inter-American Juridical Committee}

The Alvarez-Machain decision was the subject of a juridical opinion of the InterAmerican Juridical Committee. ${ }^{31}$ At the request of the presidents of the Cono Sur countries, ${ }^{32}$ the Permanent Council of the Organization of American States (OAS) requested the opinion.

The Committee's opinion, issued on August 15, 1992, was approved by nine votes in favour, with one abstention: Seymour J. Rubin of the United States. The Committee concluded that the reasoning of the US Supreme Court decision was contrary to the norms of international law. It observed that by affirming the jurisdiction of the United States of America to try individuals who are brought by force from their country of origin, the decision ignores the obligation of the United States to return Alvarez to the country from whose jurisdiction he was kidnapped. ${ }^{33}$

This opinion clearly has no binding effect and is soft law. Nevertheless, the opinion should be accorded some evidentiary weight in determining what is to be considered customary international law because the members of the Inter-American Juridical Committee are international law experts of various Member states. Apart from this, the opinion also reflects the stand these countries would take in such a situation.

\subsection{The CARICOM}

The Conference of Heads of Government of the Caribbean Community (CARICOM) ${ }^{34}$ the Community's supreme authority, issued the following statement:

The Heads of Government of the Caribbean Community take note of the recent decision of the US Supreme Court in the Alvarez-Machain Case and the circumstances leading up to that decision. The Heads of Government emphatically reject the notion that any state may seek to enforce its domestic law by means of [the] abduction of [a] person from the territory of another sovereign state with the intention to bring them within its jurisdiction in order to stand trial on criminal charges. Such actions constitute a violation of the most fundamental principles of international law and must be unequivocally condemned by the international community. ${ }^{35}$

\footnotetext{
31 "Kidnapping suspects abroad: Hearings before the Subcommittee on Civil and Constitutional Rights of the Committee on the Judiciary", 13 HRLJ (1992), at 395.

32 Argentina, Brazil, Bolivia, Chile, Paraguay, and Uruguay.

33 Ibid. See also Wilske and Schiller, loc. cit., n. 3.

${ }^{34}$ CARICOM was founded in 1973 by agreement of Commonwealth Caribbean Heads of Government, on the signing of the Treaty of Chaguaramas. Member countries of CARICOM are Antigua and Barbados, the Bahamas, Barbados, Belize, Dominica, Grenada, Guyana, Jamaica, Montserrat, St. Kitts and Nevis, St. Lucia, St. Vincent and the Grenadines, Suriname, and Trinidad and Tobago, cited in Wilske and Schiller, loc. cit., n. 3.

35 Secretaria de Relaciones Exteriores, 2 Limits to National Jurisdiction: Documents and Judicial Resolutions on the Alvarez Machain Case (1993) 7, at 13.
} 
The Conference of Heads of Government of CARICOM is a political and not a judicial body, yet the statement issued nevertheless reflects the opinio juris of the organization and the participating governments given that it reflects on how the concerned states will behave, as they are convinced it is binding upon them to do so. ${ }^{36}$

\subsection{Declarations and statements by representatives of states}

Alvarez Machain provoked many reactions by foreign governments which expressed their outrage that the United States believes it has the right to decide unilaterally to abduct one of their nationals. The Colombian government stated that it "energetically rejects the judgment issued by the United States Supreme Court"; Argentina's Justice Minister called the decision "an historic regression in criminal law"; Spain's Foreign Minister criticized the decision as "erroneous"; the lower house of the parliament of Uruguay adopted a resolution which stated that the decision shows "a lack of understanding of the most elemental norms of international law"."

\subsection{Forcible abduction under the ICCPR}

The United Nations Human Rights Committee, charged with interpreting the ICCPR and Optional Protocol, has held in four decisions (Celiberti de Casriego, ${ }^{38}$ Lopez Burgos, ${ }^{39}$ Almeida de Quinteros, ${ }^{40}$ and Garcia $^{41}$ ) that forcible abduction

36 See Shaw, Malcolm N., International Law (4th ed. Cambridge, 1997), at 67.

37 A List of 16 countries and the protests they registered towards the Alvarez Machain case, is detailed in Wilske and Schiller, loc. cit., n. 3, at 205.

${ }_{38}$ Case of Lilian Celiberti de Casariego, UN GAOR, 36th Sess., Supp. No. 40, at 185, UN Doc A/36/40 (1981) reprinted in 68 ILR 41 (1981). In this case, de Casariego, a Uruguayan/Italian citizen, was abducted from Brazil by Uruguayan agents with the connivance of Brazilian Police, brought to Uruguay, detained, and charged with subversive activities. The UN Human Rights Committee (HRC) determined that the abduction violated ICCPR Article 9(1) and that Uruguay was obligated to release and compensate de Casariego and allow her to leave the country.

${ }^{39}$ Case of Sergio Ruben Lopez Burgos, UN GAOR, 36th Sess., supp. No. 40 at 76, UN Doc. A/36/ 40, reprinted in $68 I L R,(1981)$. In this case, a Uruguayan exile in Austria brought an application on behalf of her husband, who had been abducted from Argentina by Uruguayan agents with the assistance of Argentine paramilitaries. He had been brought to Uruguay, detained and tortured. The HRC found that the forcible abduction violated ICCPR Article 9(1) and ordered that Lopez Burgos be released, compensated, and permitted to leave Uruguay.

40 Case of Almeida de Quinteros, Comm. No. 107/1981, July 21, 1983, reprinted in 2 Selected Decisions Of The Human Rights Committee Under The Optional Protocol 138 (1990). In this case, a Uruguayan national was abducted from the grounds of the Venezuelan embassy in Montevideo, Uruguay, by Uruguayan troops. Her mother, in exile in Sweden, brought an application before the HRC. Uruguay failed to comply with its obligations with regard to the application. The HRC found that responsibility for the disappearance of the applicant's daughter fell upon Uruguay, and ordered that Uruguay release her and compensate her. 
of an individual from one state to another for the purposes of his rendition to face a criminal trial (or torture) violates Article 9(1) of the ICCPR. The Committee has been remarkably vigilant in its protection of the human rights of abducted individuals. The Committee reinforced the emerging customary international law rule prohibiting the forcible abduction and transplanted the rule into the human rights context, protecting individuals qua individuals. ${ }^{42}$ This focus on the individual is heightened by the fact that the absence of protests by the injured state, of cardinal importance under customary international law, was not even considered in these cases. In fact, the active collusion in the abductions by agents of the host states would amount to consent by those states to the abductions under customary international law and preclude a finding of an international wrong. ${ }^{43}$ This fact did not, however, affect the reasoning of the Committee.

\subsection{Forcible abduction under the European Convention}

In Bozano v. France, ${ }^{44}$ an Italian Court had convicted the applicant in absentia and sentenced him to life imprisonment for offences including abduction, murder, and indecent assault. He fled to France, where he was arrested. A French Court refused Italy's request for the applicant's extradition, and he was eventually released from custody. The applicant claimed that soon after his release, he was abducted by plain-clothes police officers, served with a deportation order, driven to the Swiss border, escorted to a Swiss police station, and informed that Italy was seeking his extradition. He was later extradited to Italy and imprisoned there.

Bozano challenged his abduction, both under French domestic law and through applications to the European Commission. In his application against France, he argued that his deportation to Switzerland had violated his rights to personal liberty and freedom of movement, contrary to Article 5(1) of the European Convention. The Commission upheld his complaint, and the court found his deportation to be unlawful and incompatible with the "right to security of the person" contained in Article 5(1). The Court thus concluded that France had acted unlawfully in circumventing regular extradition proceedings, so that there was insufficient justification for the detention

${ }^{41}$ Garcia v. Ecuador, Hum. Rts. Comm., 43rd Sess., Annex, UN Doc. CCPR/C/43/D/319/1988 (1991). In this case Garcia, a Colombian citizen, was abducted in Ecuador by Ecuadorian agents at the behest of the US Drug Enforcement Agency (DEA), and deported to the United States to face drug trafficking charges. As a non-signatory, no action could be brought against the United States under the ICCPR. However, the HRC found Ecuador in violation of ICCPR Article 9(1). Ecuador conceded that there were administrative and procedural irregularities, and gave assurances that it was investigating the matter.

${ }^{42}$ Michell, loc. cit., n. 3.

43 Jennings, R. and Watts, A., (eds.), 1 Oppenheim's International Law (Longman, 9th ed., 1992), at 1194. See also the Temple of Preah Vihear case in which the Siamese authorities were held to have acquiesced in events against which they failed to protest in circumstances that called for some reaction within a reasonable period: ICJ Rep. 1962, at 22-3, 27-31.

$449 \operatorname{EHRR}(1987)$, at 297. 
of the applicant. While the court held that it did not have the power to order his release, it did order that he be financially compensated. ${ }^{45}$

A similar issue was considered by the European Commission and Court of Human Rights in Stocke v. Germany. ${ }^{46}$ In this case a German national, living in France, was tricked into re-entering Germany by a police informant. He was immediately arrested and was later convicted of several tax-related offences and sentenced to six years' imprisonment. Both the Commission and the Court held that state involvement in the deception had not been proved. Accordingly, the European Convention on Human Rights did not apply. However, the Commission was quite clear in its reasons that if involvement on the part of the German authorities had been proved then a violation of the Convention would have been established. ${ }^{47}$ Given its decision with respect to the lack of state involvement, the Court did not find it necessary to comment on this point. The Commission's reasoning, therefore, still stands. ${ }^{48}$ It should be noted that in this case, there was no allegation of a "forcible abduction" but mere "trickery". Despite that the Commission's reasoning suggests that in cases involving such "trickery", it would violate Article 5(1).

The latest case to attract world-wide attention with regard to the issue of abductions is Ocalan v. Turkey. ${ }^{49}$ In this case the Applicant was accused of founding an armed gang in order to destroy the integrity of the Turkish State and of instigating terrorist acts resulting in loss of life. The Applicant submitted that the there was prima facie evidence that he had been abducted by the Turkish authorities (operating overseas in Kenya) beyond their jurisdiction and therefore his trial would violate Article 5 of the Convention. The Court found, however, that there was no act of abduction as the Kenyan Government had co-operated with the Turkish authorities and had in fact "handed over" the applicant to them. It distinguished other cases ${ }^{50}$ by stating that while they pertained to situations where the applicant was physically forced to return to a country by government officials and was subject to the authority and control of a particular country following his arrest and return, in the instant case jurisdiction over the Applicant was gained with the active knowledge and assistance of the Kenyan authorities. The Court, relying on Soering vs. the United Kingdom, ${ }^{51}$ observed that:

\footnotetext{
45 Bozano v. France (Just Satisfaction), 13 HRR (1987), at 428, 430, wherein France was ordered to pay Bozano 100,000 FF damages and legal costs.

${ }_{46}$ Stocke v. Germany, ECHR, Ser. A, No. 199. The Commission's decision is dated 12 October 1989. The decision of the Court is dated 19 March 1991. See also Canon Garcia v. Ecuador, 5 November 1991, UN Doc. CPR/C/43/D/319/1988.

${ }^{47}$ Ibid., Decision of the Commission at 24, paras. 164-168.

48 Rayfuse, Rosemary, "International abduction and the United States Supreme Court: The law of the jungle reigns", $42 \operatorname{ICLQ}$ (1993), at 892.

49 Cf. ECHR, (Application no. 46221/99) Judgment, Strasbourg, 12 March 2003.

50 Bozano v. France, n. 44. Freda v. Italy, application no. 8916/80, Commission decision of 7 October 1980, (DR) 21, at 250; Illich Sanchez Ramirez v. France (application no 28780/95, Commission decision of 24 June 1996, DR 86, at 155); Bankovic and Others v. Belgium and 16 Other Contracting States (dec.) [GC], no. 52207/99, ECHR 2001-XII).

517 July 1989 , Ser. A, No. 161 , at $35, \S 89$.
} 


\begin{abstract}
Inherent in the whole of the Convention is a search for a fair balance between the demands of the general interest of the community and the requirements of the protection of the individual's fundamental rights. As movement about the world becomes easier and crime takes on a larger international dimension, it is increasingly in the interest of all nations that suspected offenders who flee abroad should be brought to justice. Conversely, the establishment of safe havens for fugitives would not only result in danger for the State obliged to harbour the protected person but also tend to undermine the foundations of extradition. ${ }^{52}$
\end{abstract}

While the above decisions would lead to a conclusion that under the European Convention there exists a norm preventing exercise of jurisdiction over abducted fugitives, it can also be seen that some Courts (as in the case of Ocalan) do lean towards carving out certain exceptions to such a norm. Some of these exceptions are discussed in Part Five of this paper.

\title{
2.7. The International Criminal Tribunal for the Former Yugoslavia
}

In the case of Slavko Dokmanovic, ${ }^{53}$ it was argued that Dokmanovic was arrested in a 'tricky way', which can only be interpreted as a 'kidnapping' and that this violated the sovereignty of the Federal Republic of Yugoslavia (FRY) and international law. ${ }^{54}$ The ICTY ruled that "the means used to accomplish the arrest of Mr. Dokmanovic neither violated principles of international law nor [violated] the sovereignty of the FRY [sic]". 55

The Tribunal focused on the distinction between luring and forcible abduction, believing that the former was acceptable while the latter might constitute grounds for dismissal in a future case. ${ }^{56}$ This precedent goes to show effectively that when luring is resorted to, there cannot be a violation of a state's sovereignty and that luring does not, thus, amount to a violation of international law. ${ }^{57}$

Whereas irregular rendition consists of unilateral action, no co-operation among states, no consent, and a violation of territorial sovereignty, it has been observed that luring criminal suspects into international waters is a different form of rendition since only one sovereign nation is involved in this type of action. It can thus be argued

\footnotetext{
52 Ocalan v. Turkey. Cf. ECHR, (Application no. 46221/99) Judgment, Strasbourg, 12 March 2003 at $\$ 90$.

53 Prosecutor v. Slavko Dokmanovic, Decision on the Motion for Release by the Accused Slavko Dokmanovic, No. IT-95-13a-PT, T., Ch. II, 22 October 1997.

54 See ibid., at paras. 16-18.

55 Ibid., at para. 88.

56 Snyder, Benjamin, "When, if ever, will an illegal arrest result in the dismissal of the charges" at http://www.nesl.edu/center/wcmemos/2000/snyder_files/SNYDER_M .htm, last visited 20 July 2003.

57 United States v. Yunis, 859 F.2d 953 (DC Cir. 1988).
} 
that luring eliminates the potential offence of violating territorial sovereignty. ${ }^{58}$ Indeed, this is the reasoning taken by the ICTY in the case of Slavko Dokmanovic.

\section{THE EVOLVING CUSTOMARY INTERNATIONAL LAW NORM}

Customary international law exists when "a clear and continuous habit of doing certain actions has grown up under the aegis of the conviction that these actions are, according to international law, obligatory or right". ${ }^{59}$ There are, thus, two components to customary international law: a habit or practice of doing some act, and a conviction that such an act is legally required of the state. This latter aspect of international custom is referred to as opinio juris. ${ }^{60}$

While some states have altogether rejected the mala captus bene detentus doctrine, others have taken a discretionary approach. On the other hand, international tribunals have held that some methods of bringing an individual into the jurisdiction of a state, e.g., luring or using trickery to establish jurisdiction over an individual, would not vitiate the exercise of jurisdiction. The common thread that runs through the above analysis of state practice and opinio juris, however, seems to indicate that the doctrine of mala captus bene detentus has considerably weakened from the Alvarez Machain position. In fact, in cases which involve clear violation of human rights, e.g., the use of torture, or in cases which involve an unreasonable incursion into the territory of another state, customary law will most certainly prohibit exercise of jurisdiction over individuals so apprehended. Another reason for the strong reaction is probably because states did not want to authorize or ratify the actions of the United States in Alvarez Machain, since by such authorizing or ratifying they would consequently risk a situation where powerful states would effectively end up exercising jurisdiction over individuals in other states by resorting to state-sponsored abductions.

At the same time, states have left for themselves a window open, which allows a "discretionary approach". This approach would essentially allow a judicial body of a state to decide on a case-by-case basis whether or not it would be appropriate to exercise jurisdiction, as some states did not want completely to relinquish such a power.

These slight differences in the views of states have led to some confusion as to what constitutes the exact customary norm with respect to abductions. It is sub-

\footnotetext{
58 Laflin, Melanie M., "Kidnapped terrorists: Bringing international criminals to justice through irregular rendition and other quasi-legal options", 26 J. Legis (2000), at 315.

${ }^{59}$ Jennings and Watts, op. cit., n. 43, at 26-27. See generally Brownlie, Ian, Principles of Public International Law (Oxford: Clarendon, 4th ed., 1990), at 434. According to the Restatement, "Customary international law results from a general and consistent practice of states followed by them from a sense of legal obligation." 1 Restatement (Third) of Foreign Relations Law of the United States (1987), section 102(2).

60 "For a practice of states to become a rule of customary international law it must appear that the states follow the practice from a sense of legal obligation." Restatement, n. 58, section $102 \mathrm{cmt}$. c. See also Asylum Case (Peru and Colombia), ICJ Rep. 1950, at 276, 277.
} 
mitted that in most cases, however, courts would be utilizing the "discretionary approach" and proceed on a case-by-case basis. This would not diminish the power of national jurisdictions yet would still leave them the option not to exercise jurisdiction over abducted individuals.

Most national courts inquire into the circumstances of the apprehension of alleged offenders and decline jurisdiction in cases of forcible abduction from abroad. The strong reaction and protest of states in the aftermath of Alvarez-Machain confirm this trend. ${ }^{61}$ States do not want other states to enjoy the fruits of illegal conduct. In order to become a rule of customary international law, the relevant practices, such as those reviewed in this paper, may be of comparatively short duration, but they must be general and consistent. ${ }^{62}$

The requirements have arguably been met to create a customary rule of international law in the kidnapping cases. However, the precise limits of this restriction are not exactly clear. Most of the cases discussed above have adopted a "discretionary approach", by which the courts would essentially look into the facts and circumstances of each particular case, and to come to a decision as to when it would dismiss a case and hold that the abducted person should be returned. International law today would require a predominance of this "discretionary approach". This is particularly owing to the added protection gained by criminal offenders by virtue of the world's having become a 'smaller' place. Committing a crime and escaping to a foreign jurisdiction is commonplace in most cases. With terrorism increasing and the attempts at the continuing apprehension and prosecution of war criminals by the war crime tribunals, it would be unreasonable to hold that states and international bodies be denied the right of apprehending such perpetrators, when other alternatives are not feasible.

The paper will now turn to identifying these circumstances which would be allowable under the ambit of contemporary international law.

\section{CROSSING THE LIMIT: CIRCUMSTANCES IN WHICH ABDUCTION IS ILLEGAL}

This section of the paper aims to identify principles for the development of the law governing the exercise of the abuse of process jurisdiction in transnational abduction cases. The basic considerations ${ }^{63}$ that should guide any court in deciding whether or not abduction should vitiate proceedings should be;

a) Whether there has been a violation of customary international law or an extradition treaty;

b) Whether there has been any gross violation of human rights.

\footnotetext{
${ }^{61}$ See Wilske and Schiller, loc. cit., n. 3.

62 North Sea Continental Shelf Cases (Germany v. Denmark; Germany v. Netherlands), ICJ Rep. 1969 , at 3, wherein the Court observed "The passage of only a short period of time is not necessarily, or of itself, a bar to the formation of a new rule of customary international law". See also Restatement, n. 58, section $102 \mathrm{cmt}$ b.

${ }^{63}$ Michell, loc. cit., n. 3.
} 
The following criteria should therefore be looked into by any court in determining whether an action is illegal or can be justified.

\subsection{The necessity for state involvement}

Domestic authorities must act before a judicially cognizable abuse of process exists. Domestic executive lawlessness is the essential factor. ${ }^{64}$ In the absence of action by the domestic executive there is no unlawfulness sufficient to give rise to a stay of proceedings. The abduction must have been carried out by state agents, either state employees or private individuals working under state direction. ${ }^{65}$ The distinction between abduction by state agents, on the one hand, and private citizens, on the other, is important because international wrongfulness and state responsibility are traced through an agency relationship. ${ }^{66}$ Conversely, an abduction carried out by private actors without state consent or direction is not attributable to the state subject to the fulfillment of the criteria of due diligence by the state. ${ }^{67}$ However, the action of private abductors, while not initially engaging its responsibility, may become attributable to a state if subsequently condoned by it. ${ }^{68}$

\subsection{Illegality of action}

Under the rules of international law, domestic courts have clear authority to find an abuse of process, especially given the existence of a clear customary rule against transnational forcible abduction. There are alternative bases for this authority: the territorial sovereignty of the foreign state; treaty obligations, particularly under extradition treaties, owed to the foreign state: and international human rights obligations owed directly to individuals. A fugitive should be permitted to advance evidence that his entrance to a court's jurisdiction took place in violation of international law. If the fugitive can discharge this burden, this factor should weigh in favour of a stay

${ }^{64}$ Schmidt I, [1995] 1 App. Cas at 356 (Sedley J.), noting that Lord Giffiths in Bennett made "not physical force but executive lawlessness the critical factor".

${ }_{65}$ In Alvarez-Machain the abductors were Mexican citizens employed by the US Drug Enforcement Agency.

${ }_{66}^{6}$ Velasquez Rodriguez Case (Merits), 95 ILR 259, 296, at $§ 170$ (Inter-Amer. Ct. Hum. Rts. 1988) The arbitrary detention of an individual by state agents is attributable to the State. Under international law a State is responsible for the acts of its agents undertaken in their official capacity and for their omissions, even when those agents act outside the sphere of their authority or violate internal law; See also Meron, Theodor, "International responsibility of states for unauthorised acts of their officials", 33 BYIL (1957), at 85.

67 Jennings and Watts, op. cit., n. 43, at 549.

${ }^{68}$ Case Concerning United States Diplomatic and Consular Staff in Tehran (US v. Iran), ICJ Rep. 1980, at 3, 35 (Iran was held liable for occupation of US Embassy and consulates due to its adoption of private acts). See also the Commentary on ILC Draft Articles, YILC 1974, II, 28 (Cases such as Eichmann cited as examples of the imputability of the acts of private individuals to a state). 
of proceedings. The following acts would result in the becoming illegal of executive action.

\subsubsection{Violation of human rights}

Among the best recognized and documented fundamental human rights are the right to liberty and security of the person, and the right to freedom from arbitrary arrest and detention. These rights are set out in the Universal Declaration of Human Rights, ${ }^{69}$ the International Covenant on Civil and Political Rights, ${ }^{70}$ the European Convention on Human Rights, ${ }^{71}$ the American Declaration on the Rights and Duties of Man, ${ }^{72}$ and the American Convention on Human Rights. ${ }^{73}$ These rights are also guaranteed by the constitutions of many nations. It is, therefore, without a doubt that the rights to liberty and security of the person and to freedom from arbitrary arrest are rights which, in addition to being set out in the instruments referred to above, are now firmly rooted in the corpus of customary international law.

For an abduction to prejudice the outcome of a trial, it was held in ex rel Lujan v. Gengler ${ }^{74}$ that a fugitive must first establish that the governmental conduct in question "shocks the conscience". The standard for a human rights violation in an abduction case was identified as any action that would "shock the conscience" of the court. This exception allows a government to abduct suspected terrorists from international waters while still safeguarding the human rights of the abductees. By this ruling, the courts affirmed the jurisdiction and responsibility of law enforcement in overseas abduction cases, but sent a clear message that gross human rights violations would not be tolerated. For instance, torturing the individual concerned would amount to a violation. ${ }^{75}$ Even in cases where excessive violence has been used, such action would weigh heavily in favour of a stay. For example, in the abduction of Fawaz Yunis, ${ }^{76}$ US officials broke both of Yunis' wrists. Violence in a rendition on the part of the domestic authorities should be considered a prima facie ground for ordering a stay of prosecution. ${ }^{77}$

\footnotetext{
${ }^{69}$ See, Arts. 2 and 9, Universal Declaration of Human Rights, GA Res. 217A, UN Doc. A/811, at 71 (1948).

${ }^{70}$ See, Art. 9, International Covenant on Civil and Political Rights, GA Res. 2200, 21 UN GOAR, Supp. (No. 16) 52, UN Doc. A/6316 (1966).

${ }^{71}$ See, Art. 5, European Convention for the Protection of Human Rights and Fundamental Freedoms, 1950, 213 UNTS 221.

72 See, Arts. 1 and 25, American Declaration on the Rights and Duties of Man, 1948.

73 See, Art. 7, American Convention on Human Rights, OAS Treaty Series No. 36, 1144 UNTS 123.

74510 F.2d 62 (2d Cir. 1975).

75 United States v. Toscanino, 500 F. 2d 267 (2d Cir. 1974).

76 United States v. Yunis, 859 F.2d 953, 955 (DC Cir. 1988).

77 Michell, loc. cit., n. 3.
} 


\subsubsection{Violation of territorial sovereignty of injured state}

Abducting a person from a foreign country is a gross violation of international law and gross disrespect for a norm that is high in the opinion of mankind. ${ }^{78} \mathrm{~A}$ nation's agents may not seize an individual from another nation without obtaining consent from the other nation's government. ${ }^{79}$

The Jacob Kidnapping Case, ${ }^{80}$ between Switzerland and Germany, is an example of how acts of abduction and thereby bringing an individual into the jurisdiction of the country to have committed the abduction amount to a violation of the sovereignty of the other state. ${ }^{81}$ The matter was referred to arbitration ${ }^{82}$ and Jacob was returned to the Swiss authorities. In the case of Eichmann, ${ }^{83}$ Argentina protested the violation of its sovereignty, requested the return of Eichmann, and eventually took the matter to the United Nations. The Security Council adopted a resolution condemning the kidnapping and requesting Israel to make appropriate reparation. ${ }^{84}$

It is well established that where an act of abduction is effectively carried out, an infraction of the sovereignty of the host state has been committed. ${ }^{85}$ The Harvard Draft Convention on Jurisdiction with respect to crime states;

No State shall prosecute or punish any person who has been brought within its territory or a place subject to its authority by recourse to measures in violation of international law or international convention without first obtaining the consent of the State or States whose rights have been violated by such measures. ${ }^{86}$

It needs to be noted, and is also evident from the above, that only if the injured state raises a complaint of a violation of its sovereignty is the abducting state under

${ }^{78}$ Henkin, Louis, “A decent respect to the opinion of mankind”, 25 John Marshal LJ (1992), at $215,231$.

79 Paust, Jordan J., Bassiouni, M. Cherif, et al., International Criminal Law (Carolina Academic Press, 1996), at 426.

${ }^{80}$ Preuss, Lawrence, "Kidnapping of fugitives from justice on foreign territory", 29 AJIL (1935), at 502 (discussion on Jacob Kidnapping Case).

${ }^{81}$ Note of the Federal Council to the German Foreign Office, 1 April 1935. Text in Journal de Geneve, 3 April 1935.

${ }^{82}$ The case was arbitrated under the Treaty of Arbitration and Conciliation of 3 December 1921, 12 LNTS 281.

${ }^{83}$ Attorney-General of the Government of Israel v. Adolf Eichmann, 36 ILR 5 (Isr. Sup. Ct. 1962).

${ }^{84}$ See generally UN SCOR, UN Doc.S/RES/4349 (1960).

${ }^{85}$ See also Lowenfeld, Andreas F., "U.S. law enforcement abroad: The constitution and international law, continued", 84 AJIL (1990), at 444; Id., "Kidnapping by government order: A follow-up", ibid., at 712; O'Higgins, Paul, "Unlawful seizure and irregular extradition", BYIL (1960), at 279.

${ }^{86}$ See Article 16 of Harvard Research in International Law, "The Draft Convention on Jurisdiction with Respect to Crime”, 29 AJIL (1935), at 442, 623. 
an obligation to return the individual. It is obvious that the individual cannot by himself claim a violation of a state's sovereignty. ${ }^{87}$

\subsubsection{Circumvention of an Extradition Treaty}

In many cases of abduction the executive illegality at issue is the circumvention of extradition relations with that foreign state from which the fugitive was abducted. There can be little doubt that this question formed a central element of the grounds for the decision in Bennett and has been appreciated by various other Courts. ${ }^{88}$ It can, thus, safely be concluded that in any case where an extradition treaty has been circumvented, that act will be termed as "illegal conduct" and will not be allowed to stand.

\section{DEFINING ACCEPTABLE LIMITS: THE CIRCUMSTANCES IN WHICH THE ACTS CAN BE JUSTIFIED}

As noted earlier, despite the extreme reaction of states to the Alvarez Machain case, most states would adopt a discretionary approach. This section of the paper seeks to define the limits within which this discretionary approach may be utilized in bringing an individual to within the jurisdiction of one state from another one.

\subsection{When the abduction was not "forcible"}

The observations of the International Criminal Tribunal for the Former Yugoslavia, in Slavko Dokmanovic, ${ }^{89}$ are important: the ICTY ruled that "the means used to accomplish the arrest of Mr. Dokmanovic neither violated principles of international law nor [violated] the sovereignty of the FRY (sic)". 90 The Tribunal focused on the distinction between luring and forcible abduction, believing that the former was acceptable while the latter might constitute grounds for dismissal in a future case. ${ }^{91}$

\footnotetext{
87 See Gluck, Jonathan A., "The customary international law of state sponsored international abduction and United States Courts", 44 Duke LJ (1994), at 612.

${ }^{88}$ Regina v. Bow Street Magistrates (Ex parte Mackeson), [1981] 75 Crim App 24; State v. Ebrahim, 31 ILM 888; Levinge v. Director of Custodial Services, 9 NSWR 546 (Ct App 1987); Bozano v. France, 9 EHRR (1987), at 297; Soering vs. the United Kingdom, 7 July 1989, Series A, No. 161, at $35, \S 89$.

${ }^{89}$ Prosecutor v. Slavko Dokmanovic, Decision on the Motion for Release by the Accused Slavko Dokmanovic, No. IT-95-13a-PT, T., Ch. II, Oct. 22, 1997.

90 Ibid., at para. 88.

91 Ibid., at para. Snyder, loc. cit., n. 56.
} 
In the same breath, however, the views of the European Commission of Human Rights in Stocke v. Germany ${ }^{92}$ are important because, in this case, luring and utilizing trickery, had it in the opinion of the European Commission been proved, would have amounted to a violation of the European Convention on Human Rights. ${ }^{93}$

These conflicting observations have created a situation of ambiguity in cases where the presence of the fugitive was procured through non-forcible ways. That which, however, constitutes a crucial distinction is the nature of the offence in each of the cases. While in Dokmanovic,${ }^{94}$ the allegations against the accused were for being responsible for the single greatest massacre of the 1991 war in Croatia, (that of the execution of 261 people forcibly taken out of a hospital in Vukovar, eastern Croatia), on the other hand, in Stocke, ${ }^{95}$ the allegations against him were "tax-related offences". It is clearly evident that the nature of the crime in each of the cases would have played a crucial role in the Courts' having reached their respective opinions.

There is no qualitative difference between abduction by force, and that by fraud. Abduction is the removal of a person from the jurisdiction of one state to another by force, the threat of force or by fraud. ${ }^{96}$ Most countries do not distinguish between abduction by fraud and abduction by force. In recognition of this trend, in September of 1994, the XVth Congress of the International Penal Law Association adopted a resolution which stated:

\begin{abstract}
Abducting a person from a foreign country or enticing a person under false pretenses to come voluntarily from another country in order to subject such a person to arrest and criminal prosecution is contrary to public international law and should not be tolerated and should be recognized as a bar to prosecution. ${ }^{97}$ (emphasis added)
\end{abstract}

However, while abduction by force will almost certainly create a strong presumption in favour of issuing a stay, the status of abduction by fraud is less clear. As the Privy Council recognized in Liangsiriprasert, ${ }^{98}$ the police must be accorded a certain amount of leeway to combat sophisticated international criminal activity through the use of ruses and tricks. It was further observed in Regina v. Latif and Shahzad ${ }^{99}$

92 Stocke v. Germany, ECHR Ser. A, No. 199. The Commission's decision is dated 12 October 1989. The decision of the Court is dated 19 March 1991. See also Canon Garcia v. Ecuador, 5 November 1991, UN Doc. CCPR/C/43/D/319/1988.

93 Rayfuse, loc. cit., n. 5, at 892.

94 Prosecutor v. Slavko Dokmanovic, n. 89.

95 Stocke v. Germany, n. 46.

${ }^{96}$ Shearer, I.A., Extradition in International Law (1971), at 72-73. See also Gilbert, Geoff, Aspects of Extradition Law (1991), at 115.

97 "Mutual assistance in criminal matters: XVth Congress of International Penal Law Association adopts resolutions", 10 Int'l Enforcement L. Rep. (1994), at 385, 386, 387. See also Scharf, Michael P., "Irregular rendition and the Yugoslavia Tribunal", available at http://www.nesl.edu/center/ Asilnews/asils98.htm, last visited 25 July 2003.

98 Liangsiriprasert, [1991] 1 App. Cas, at 243; United States v. Yunis, 681 F. Supp. 896 (DDC 1988), 924 F. 2d 1086 (fugitive lured into international waters by promise of lucrative drug deal). 99 [1996] 1 WLR 104. 
that there would be no abuse of process to lure the defendants into England by deceit for their alleged part in a drug trafficking scheme.

The real question is, therefore, how far the police may go before their conduct becomes objectionable. It is submitted that cases such as Liangsiriprasert, where the fugitives entered Hong Kong to pick up payment for drug shipment of their own free will and "not because of any unlawful conduct of the authorities but because of their own criminality and greed", and cases like Dokmanovic, where a war criminal was lured by the incentive of possible compensation for his property in Eastern Slovakia which he had been forced to abandon, cannot be cases where the police exercise (although, technically speaking, an abduction) can be said to be unjustified.

The force-fraud distinction has been supported on the basis of policy arguments, namely, that the fraud does not violate the territorial sovereignty of foreign states, and does not present the risk of violence to the fugitive or third parties. ${ }^{100}$

Thus, in some cases where the abduction was brought about by force or deceit, the action can be justified, and the defendant should not be entitled to a stay.

\subsection{Legitimate cases of threats to national security}

According to noted jury consultant, Derek Bowett, sending agents into a state's territory specifically to target a criminal does not violate the territorial integrity or political independence of the state. ${ }^{101}$

Given that the actions of espionage or law enforcement agents within a nation's territory have never been considered a use of force under international law, ${ }^{102}$ it follows that targeting a terrorist for abduction from another state is not necessarily a violation of international law. This can in fact be considered as an offshoot of a state's right to defend itself.

Bowett's reasoning also supports the theory that a state can seize a terrorist in another country as long as the capture is necessary to prevent future harm to its citizens and the mission's objectives are strictly confined to that task. ${ }^{103}$ Therefore, even if the terrorist has already struck, his abduction is justifiable as preventing a future attack.

French officials permitted George Habash, head of the Popular Front for the Liberation of Palestine, an extremist offshoot of the Palestine Liberation Organization, to enter and seek medical treatment in France. ${ }^{104}$ Another terrorist, Ahmed Jibril, who heads the Popular Front for the Liberation of Palestine-General Command,

\footnotetext{
100 Laflin, loc. cit., n. 58, at 315.

101 See, Bowett, Derek W., Self-Defence in International Law (Manchester: Manchester University Press, 1958), at 55 (discussing the use of forcible self-help against terrorists).

102 See ibid., at 25.

103 See ibid., at 29.

104 See Fenyvesi, Charles, "Washington whispers", U.S. News and World Rep., 24 February 1992, at 26 (commenting on the medical treatment of two Palestinian terrorists in Western Europe), in Michell, loc. cit., n. 3.
} 
boasted "that he, too, recently travelled for health reasons - twice to Switzerland and once to France." 105 The circumstances surrounding the failed extradition of Pinochet are another example. Countries such as India face a plethora of problems in managing the extradition from countries as diverse as Portugal, England, and Thailand of individuals accused of terrorism. If countries do not follow international conventions that provide the means to apprehend, prosecute, and/or extradite a terrorist, other states are left with little choice but to try and assert jurisdiction to avoid placing the harbouring state in a position where the latter may be subjected to retaliation. ${ }^{106}$

\subsection{The gravity of the offence}

It would be absurd to hold that terrorists and serious human rights violators should not be brought to trial by irregular methods, for example, by abduction. The interests of society require that such offenders be brought to trial. Conduct on the part of the domestic authorities amounting to an abuse of process in the case of a lesser offence might not amount to such an abuse where the alleged offence was more serious. This is clearly evident from the case of Eichmann, wherein the plea of Eichmann that he was abducted and should therefore not be proceeded against, was rejected, on the ground that the crimes alleged against him were of such a nature that the irregular manner of his production before court could be overlooked. This kind of an "Eichmann" exception, it is submitted, is an appropriate rule.

These methods should, however, be utilized by states only once they have exhausted all possible routes to secure the fugitive's return by normal processes. As a general rule, the prohibition of abduction has a legitimate rationale. Individuals should have the right to walk down the street without the fear of being kidnapped for unknown or undeclared reasons by a foreign government. However, under circumstances where crimes are sufficiently appalling to shock the international conscience, states must be able to balance the potential for human rights violation by abduction with the numerous human rights violations committed by notorious evildoers such as Eichmann. The moment the individual's violations far outweigh the violation of the abduction, that abduction should be permissible and should not be considered a violation of human rights.

Even if the international community accepts state-sanctioned abduction as a legitimate way to create personal jurisdiction over some alleged war criminals, concerns remain about the means utilized to execute the abduction. In order to prevent unnecessary injury to the abductees, the UN must establish procedural safeguards governing abductions. In Paust's discussion concerning state-sanctioned abduction as a human rights violation, he notes that the doctrine of human rights includes the

\footnotetext{
105 Ibid.

106 Kash, Douglas, "Abducting terrorists under PDD-39: Much ado about nothing new", 13 Am.U.ILR (1997), at 139 .
} 
right to be free from abduction. ${ }^{107}$ However, according to Paust, not all abductions fall into the category of human rights violations.

"I do not agree ... that every abduction ... in foreign state territory without foreign state consent is ... necessarily 'arbitrary,' 'cruel,' 'inhuman,' or 'degrading' within the meaning of relevant human rights standards."

Violators of jus cogens norms need to be brought to justice and in many such instances, as has already been witnessed in the ICTY, ${ }^{109}$ irregular methods of capturing such violators will need to come into play. Under such circumstances, the failure to grant jurisdiction to a Court would not only defeat the essence of the strong international law rule preventing such crimes, but would also amount to handing to offenders and potential offenders the ideal route to chart out an escape.

\section{CONCLUSION}

Despite there being a rule against the doctrine of mala captus bene detentus, statesponsored international abductions will continue in the future as states, frustrated by the inability to punish those they deem deserving, continue to resort to self-help methods of apprehension. As the clear limits of the customary rule prohibiting the rule of mala captus bene detentus are still being tested, increasing reliance will be placed by states on the "discretionary approach", giving states the option to justify all irregular acts utilized in gaining jurisdiction over individuals. Standing between such states and this anarchy is the rôle of international law.

Even in applying the "discretionary approach" states will necessarily have to conform to the accepted rules of international law and customary practice which have evolved since the early decision of Alvarez Machain. Accordingly, only in the limited cases outlined above will the state be justified in utilizing irregular methods to bring an individual within its jurisdiction.

Where the individual concerned is alleged to have committed crimes that offend the conscience of mankind, or jus cogens crimes, the interest of society requires that the crime be punished, and all that the defendant is entitled to demand is a fair trial by a court having jurisdiction of the subject matter, in which he has an opportunity of knowing the charge and of being fully heard. The creation of such an exception is necessary with the formation of tribunals such as the International Criminal Tribunal for the former Yugoslavia, since there might be situations in which methods such as abduction would have to be utilized to bring about the prosecution of individuals who have committed crimes that offend the very conscience of man, and who will be guarded by states with an interest in their non-prosecution. Illegal capture cannot

\footnotetext{
${ }^{107}$ Paust, Jordan J., "After Alvarez-Machain: Abduction, standing, denials of justice, and unaddressed human rights claims”, 67 St.John'sLR (1993), at 551, 561.

108 Ibid., at 564.

109 Prosecutor v. Slavko Dokmanovic, n. 88.
} 
be used as an obstruction to the exercise of international criminal jurisdiction. The same argument would apply against terrorists who would threaten the national security of a state.

If the UN creates appropriate procedures to regulate the abduction of alleged war criminals and terrorists, and if states are bound to follow these procedures, then principles of human rights will be preserved and can co-exist with principles of justice. UN codification would acknowledge that certain abductions are not violations of human rights. However, an explicit distinction must be made between kidnappings that do not per se represent violations of human rights, and the methods through which the abductions are actually carried out, which can violate human rights. ${ }^{110}$ Both states and individual defendants should be able to bring human rights actions against states that do not adhere to the UN procedural guidelines regarding statesanctioned abductions. Signatory nations would then defer to the judgment of the international tribunal when a violation is alleged, and the UN could determine whether a state used excessive force in light of the abduction's circumstances. If the state is found to have used excessive force, the UN would impose an appropriate sanction.

In conclusion, it can be stated that the rule of law rationales opposing the mala captus bene detentus principle - in that it brings into disrepute the administration of justice, encourages lawlessness, violates state sovereignty, disregards international human rights law, and undermines the international extradition network - is indeed overwhelming and justified. In the future, however, Courts, although recognizing that the mala captus bene detentus principle is generally inconsistent with modern international law, should not hesitate to exercise jurisdiction over those whose prosecution is essential and who could not have been proceeded against without an action of abduction, or who have committed crimes that could be classified under an "Eichmann exception".

${ }^{110}$ Izes, Beverly, "Drawing lines in the sand: When state-sanctioned abductions of war criminals should be permitted", 31 Colum.JL\&Soc.Probs. (1997), at 1. 